\title{
Patient's View of Admission to a London Teaching Hospital
}

\author{
P. HUGH-JONES,* M.D., F.R.C.P.; A. R. TANSER,* M.B., M.R.C.P.; C. WHITBY,* A.M.I.A.
}

Brit. med. F., 1964, 2, 660-664

". . . the very first requirement in a hospital is that it should do the sick no harm."-FLORENCE NigHTINGALE.

This paper gives the results of a medical and social survey of a small group of patients admitted into the beds of one medical "firm" of King's College Hospital. It was designed to provide some facts about the effects of admission on patients, from their point of view. We intended to use the results to assess the efficacy of the service we provide at present, and to form some basis for future plans about medical treatment, design of wards, and other hospital amenities.

A report issued by the Ministry of Health (1963) stated that little was known objectively about patients' reactions to treatment, and quoted only three such studies in this country (McGhee, 1961 ; Barnes, 1961 ; Haywood, Jefford, MacGregor, Stevenson, and Wooding Jones, 1961). Although empowered to do so, the subcommittee who prepared the report made no inquiries themselves. This was criticized in the British Medical fournal (1963).

In view of this Ministry of Health report and of the increasing interest in the results of medical care in the widest sense, we have prepared for publication some of the results of our survey which seemed to us to be of general interest.

\section{Material and Methods}

The Sample.-We included in the survey all patients admitted to hospital under the care of this one general medical firm (two physicians) during August, September, November, and December 1962 and February and March 1963. We hoped that this six-months sample, drawn during different seasons of the year, would be reasonably representative of our patients. A few patients who died or were transferred within 24 hours of admission were not included (because of administrative difficulties, not by choice). Most of the 275 patients included in the survey were admitted as emergencies (Table I).

TABLE I

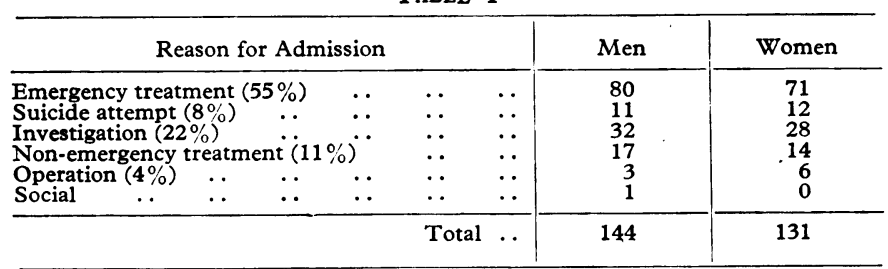

Age.-The average age of the men was 51 years and of the women 48 years, but 70 patients $(25 \%)$ were more than 65 .

Length of Stay.-Most patients stayed in hospital between two and five weeks (see Chart), women tending to stay longer than men. The longest stay was 220 days, the shortest one day.

Type of Patient.-The firm accepts general medical cases, but it also runs an asthma clinic and is linked with a Medical Research Council Unit doing research in lung disease. This accounts for the high number of patients, especially women, with respiratory disorders (Table II).

* From King's College Hospital, London.

\section{The Survey}

A questionary was prepared in three parts (see Appendix). The first two parts were completed while the patient was in the ward, and the third about a month after leaving hospital. The first part was a record of the personal and medical facts about the patient. It also included a record of iatrogenic illness, the diagnosis at the time of discharge from hospital, and the assessment by one of us (A. R. T.) of the results of treatment. The second part dealt with social problems worrying the patient when actually in hospital and was completed by a social worker (C. W.) after an interview with the patient in the ward. The patient's idea of the diagnosis was also recorded.

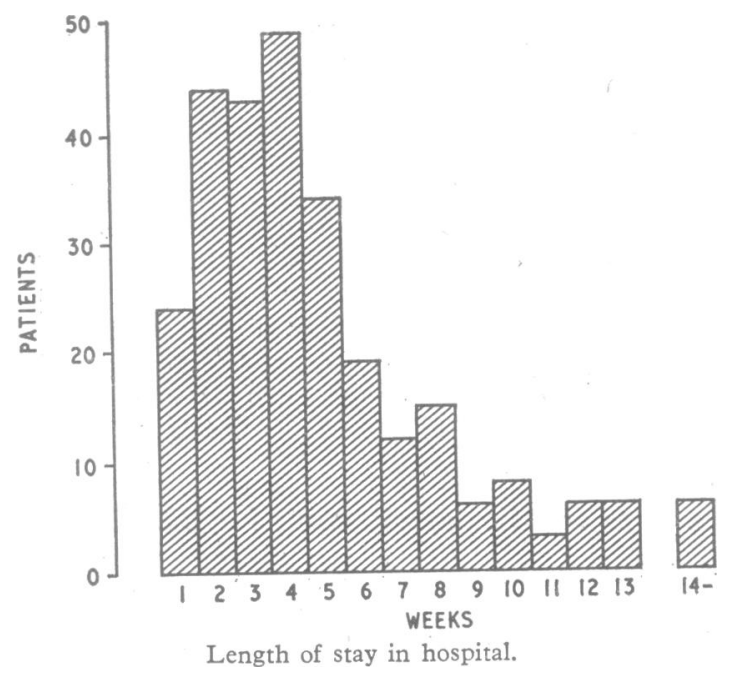

\begin{tabular}{|c|c|c|c|c|c|c|}
\hline \multicolumn{4}{|c|}{ Type } & \multirow{2}{*}{$\begin{array}{c}\text { Men } \\
31 \\
43 \\
30 \\
12 \\
28\end{array}$} & \multirow{2}{*}{$\begin{array}{c}\text { Women } \\
34 \\
28 \\
24 \\
20 \\
25\end{array}$} & \multirow{2}{*}{$\begin{array}{c}\text { Total (\%) } \\
65(23) \\
71(26) \\
54(20) \\
32(12) \\
53(19)\end{array}$} \\
\hline $\begin{array}{l}\text { Respiratory } \\
\text { Circulatory } \\
\text { Digestive } \\
\text { Psychiatric } \\
\text { Other .. }\end{array}$ & $\begin{array}{l}\because \\
\because \\
\therefore\end{array}$ & $\begin{array}{l}\ldots \\
\cdots \\
\cdots\end{array}$ & $\begin{array}{l}. \\
\because \\
\therefore\end{array}$ & & & \\
\hline
\end{tabular}

The third part recorded the patient's reactions to hospital conditions, the results of treatment, and the patient's idea of his diagnosis. In most cases the patient was interviewed for the completion of this part after the first out-patient visit after discharge from hospital-usually a month later. In some cases questionaries were sent by post, but this was avoided if possible. In Part 3 the patients were given every opportunity by the social worker to express criticism, adverse or favourable, if they wished to do so, away from the atmosphere of nurses and doctors, although the interview had to be in the hospital building.

The sections of the questionary which are relevant to this paper are listed in the Appendix.

Of the 275 patients included in the survey, 245 completed Part 2 of the questionary. Those who did not were mostly moribund, confused, or aphasic. Only one patient refused to co-operate. Part 3 was completed by 174 patients ; 46 patients 
could not do so (see Table III). The remaining 55 did not attend hospital again and failed to reply. to a postal inquiry. Of these, $21(38 \%)$ were suffering from psychological illnesses, most having been admitted to hospital after attempting suicide.

Table III.-Patients Not Completing Questionary After Discharge

\begin{tabular}{|c|c|c|c|c|c|}
\hline \multicolumn{4}{|c|}{ Reason } & \multirow{2}{*}{$\begin{array}{r}\text { Men } \\
16 \\
5 \\
5 \\
27\end{array}$} & \multirow{2}{*}{$\begin{array}{c}\text { Women } \\
12 \\
2 \\
6 \\
28\end{array}$} \\
\hline $\begin{array}{l}\text { Died in hospital } \\
\text { Died after discharge ... } \\
\text { Transferred elsewhere } \\
\text { Other reasons }\end{array}$ & $\begin{array}{l}\ldots \\
\because\end{array}$ & 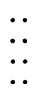 & $\begin{array}{l}\ddot{*} \\
\ddot{*}\end{array}$ & & \\
\hline
\end{tabular}

We realize that this survey is a small sample and that it may be biased by the loss of the information from these 55 patients. But this bias is mainly loss of patients admitted after suicide attempts, and we think the sample is likely to be reasonably representative of our general medical patients:

An attempt was made to make the questionary as objective as possible on the side of the interviewer. Observer variation was not a factor, since Parts 2 and 3 were completed by the one social worker.

\section{Results}

\section{Admission and Medical Care}

Reception at Hospital and Ward.-Of the 174 patients who completed Part 3, all but two were satisfied with the administrative arrangements for their admission once they arrived at the hospital. Questions were asked of the 245 patients who completed part two in the ward about their mood on admission to hospital (Table IV) ; $46 \%$ of the patients admitted from the waiting-list were apprehensive about coming into hospital; $26 \%$ of those who were admitted as an emergency also said they were apprehensive. Once admitted, $82 \%$ said they were contented with hospital conditions.

TABLE IV.-Mood on Admission

\begin{tabular}{l|c|c|c|c}
\hline & Anxious & $\begin{array}{c}\text { Anxious and } \\
\text { Relieved }\end{array}$ & Relieved & $\begin{array}{c}\text { Too Ill or } \\
\text { No Comment }\end{array}$ \\
\hline $\begin{array}{lll}\text { Emergency admissions (147) } \\
\text { Non-emergency (98) }\end{array}$ & $\begin{array}{l}25(17 \%) \\
27(28 \%)\end{array}$ & $\begin{array}{r}13(9 \%) \\
18(18 \%)\end{array}$ & $\begin{array}{r}62(42 \%) \\
45(46 \%)\end{array}$ & $\begin{array}{r}47(32 \%) \\
8(8 \%)\end{array}$ \\
\hline
\end{tabular}

Results of Medical Treatment.-Analysis 'of the 275 patients surveyed showed that $72 \%$ were considered by the doctor to be " cured" or " improved," $18 \%$ " unchanged " or "worse," and $10 \%$ died in hospital. Cured and improved were pooled, since there seemed to be no definite definition of "cured." In Table $\mathrm{V}$ the impression recorded by 174 patients who com-

Table V.-Result of Treatment (174 Patients Able to Answer Part 3 Questions)

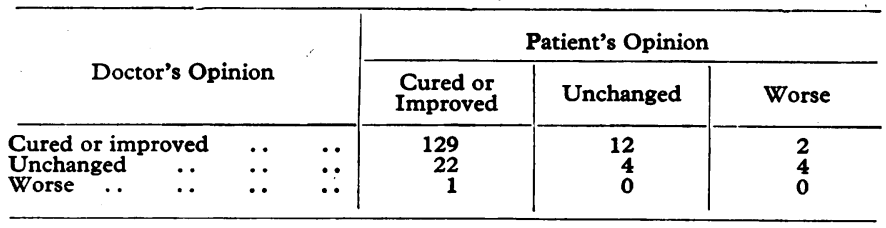

pleted part 3 after discharge is compared with the doctor's opinion: $77 \%$ of the patients agreed with the doctor, $13 \%$ were more optimistic, and $10 \%$ less satisfied.

Iatrogenic Illness.-Four patients contracted antibioticresistant staphylococcal infection in hospital, four had severe reactions to drugs, two developed bedsores, and one had persistent pain after physiotherapy. If calf-vein thrombosis is considered an iatrogenic illiness caused by being confined to bed, then a total of 18 patients $(7 \%)$ suffered potentially serious ill-effects, for seven patients developed venous thrombosis. Five of these seven had pulmonary embolism.

Anxieties in Hospital.-Because of being in hospital $38 \%$ of patients had problems which caused them more than acceptable anxiety. Men (41\%) were more worried than women $(34 \%)$. Finance $(39 \%)$, business $(25 \%)$, and family responsibilities $(25 \%)$ were the most important problems. Hire-purchase commitments concerned only six patients. Problems they would have to face after leaving hospital worried $28 \%$ of the patients : $50 \%$ of the women with such anxieties were concerned about coping at home and $35 \%$ of the men were concerned about their fitness to continue their job.

\section{Acceptance of Hospital Conditions}

Accommodation in Hospital.-Of our patients $83 \%$ were accommodated in large wards of the old-fashioned type, with 26 beds arranged opposite to each other. There were usually one or two " extra " beds in the centre of the ward. The others were in single-, two-, or three-bedded side wards. Of 174 patients answering, only $10(6 \%)$ disliked being in a large ward, but $56(32 \%)$ would have preferred to be in a single- or fourbedded ward if they had a choice. Had the hospital been organized for progressive patient-care, 9 of the 275 patients would have been treated in an intensive care unit: three of these had severe barbiturate poisoning, three had severe circulatory disturbances, and three were in respiratory failure; two of these patients died. Twenty-six patients $(9 \%)$ could have been treated in a self-care unit, with hotel-type accommodation. These patients were undergoing investigations which did not require close observation. The average length of stay for these patients would have been 17 days.

Food.-Diet plays an important part in treatment, and $38 \%$ of all patients had a special diet. Of those on a therapeutic diet, $46 \%$ needed some form of salt-restriction. Most special diets, particularly if salt is restricted, are less palatable than ordinary food, but the patients receiving such diets did not complain about the food more than those on a normal diet. In all, $14 \%$ of the 174 patients asked thought the food was unsatisfactory.

Visiting-hours.-Although there are official visiting-hours, relatives who are unable to come at these times may visit at other times by arrangement with the ward sister. During the week the visiting-hours are from 7 to 7.30 p.m.- $35 \%$ of the 174 patients thought that this was too little. One man said it was too long. At week-ends visitors are allowed from 2.30 to 3.30 p.m. on Saturday and from 2 to 3.30 p.m. on Sunday$5 \%$ thought this too short and $12 \%$ said it was too long. $81 \%$ of patients said their visitors were able to come regularly; $23 \%$ said they would have liked unlimited visiting-hours.

Noise.-It is very difficult to measure the nuisance value of noise. Tenfold increases in intensity of sound are appreciated by the human ear as equal increases in loudness. If the intensity of the softest sound which can be heard is 0 , then a whispered voice 3 feet $(91 \mathrm{~cm}$.) from the ear represents an increase in intensity of a thousandfold, or 3 bels or 30 decibels. Noise is a mixture of sound frequencies which will be appreciated differently by different ears. Thus age will lessen the effect of high-frequency noise, so that an old man will be less disturbed than a young man by the high-frequency noise of a Wright's nebulizer (used in the treatment of asthma and bronchitis). Loudness also depends on distance from the source and whether sound waves are concentrated by reflecting surfaces (" echoes"). The disturbance caused by noise is related to the increase in intensity above the background-noise level. A loud noise in a noisy ward may, in itself, be less disturbing than a softer noise in a quiet room. The Wernher Research Unit of the Medical Research Council kindly recorded some noise levels in our male ward at midday (Table VI). All readings were taken on the 
" A" scale rating frequency response, which corresponds subjectively with normal hearing. Metal dressing trolleys, the changing of oxygen cylinders, and the telephone caused considerable noise. Of 174 patients, $21 \%$ complained about noise in our questionary. Those who mentioned the source of the noise were particularly troubled by other patients who were

TABLE VI.-Noise Levels at Noon. " A" Scale Rating in Decibels

\begin{tabular}{|c|c|c|}
\hline Source & Average $\mathrm{dB}$ & Peak dB \\
\hline 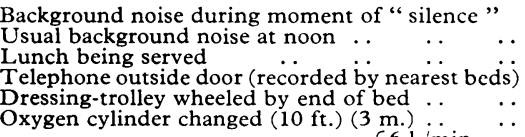 & $\begin{array}{l}40 \\
53 \\
55 \\
59 \\
62 \\
64\end{array}$ & $\begin{array}{l}60 \\
60 \\
70 \\
70\end{array}$ \\
\hline Wright's nebulizer at $1 \mathrm{ft} .(30 \mathrm{~cm}). \begin{cases}01 / \mathrm{min} . & \ldots \\
41 . / \mathrm{min} . & \ldots\end{cases}$ & $\begin{array}{l}\text { (near } 4,000 \mathrm{c} . / \mathrm{sec} .) \\
\text { (near } 3,000 \mathrm{c} . / \mathrm{sec} \text {.) }\end{array}$ & \\
\hline
\end{tabular}

Comparison figures (Hood, 1957): Quiet garden $=20 \mathrm{~dB}$; busy street $=60 \mathrm{~dB}$.

very ill or mentally disturbed, and by the telephone ringing at night. Since the background-noise level at night (which was not recorded) might be expected to be about 30 decibels, and the telephone was recorded at 59 decibels by the nearest beds, this complaint seems amply justified.

Undergraduate Teaching.-We wished to know the amount of use we made of cases for undergraduate teaching and also how much distress this caused the patients. Table VII shows the cases used for teaching. Of the 174 patients who answered the question asking if they remembered a teaching session round their bed (question 37-see Appendix), $62 \%$ said they did so. $70 \%$ of the men were taught on and $50 \%$ of the women. Nine women out of $45 .(20 \%)$ and three men out of $63(5 \%)$ disliked being taught on.

TABLE VII.- Scope of Undergraduate Bedside Teaching. Compiled from \begin{tabular}{c|c|c}
\multicolumn{2}{c}{ Patients Who Answered the Question on Teaching } \\
\hline Disease & No. Taught On & No. Not Taught On \\
\hline
\end{tabular}

\begin{tabular}{|c|c|c|c|c|c|}
\hline \multicolumn{4}{|c|}{ Discaso } & 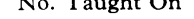 & 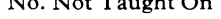 \\
\hline \multicolumn{4}{|l|}{ Respiratory: } & & \\
\hline \multirow{2}{*}{\multicolumn{2}{|c|}{$\begin{array}{l}\text { Tuberculosis } \\
\text { Carcinoma of bronchus }\end{array}$}} & $\cdots$ & . & 4 & 1 \\
\hline & & . & $\cdots$ & 2 & 2 \\
\hline \multicolumn{2}{|c|}{ Pleural effusion } & $\cdots$ & . & 1 & $\overline{3}$ \\
\hline \multicolumn{3}{|c|}{$\begin{array}{lll}\text { Pneumonia } & \\
\text { Bronchitis/asthma } & \cdots & .\end{array}$} & $\cdots$ & $\begin{array}{r}2 \\
14\end{array}$ & 3 \\
\hline \multicolumn{3}{|c|}{ Spontaneous pneumothorax } & $\because$ & $\begin{array}{r}14 \\
2\end{array}$ & \\
\hline \multirow{2}{*}{\multicolumn{2}{|c|}{$\begin{array}{l}\text { Other } \ldots \\
\text { Gastro-intestinal: }\end{array}$}} & .. & . & 1 & 1 \\
\hline & & & & & \\
\hline \multirow{2}{*}{\multicolumn{2}{|c|}{$\begin{array}{l}\text { Peptic ulcer or carcinoma } \\
\text { Haematemesis/melaena }\end{array}$}} & . & . & 7 & 6 \\
\hline & & $\cdots$ & . & 4 & 4 \\
\hline \multicolumn{3}{|c|}{ Liver or gall-bladder disease } & . & 3 & 2 \\
\hline \multicolumn{2}{|c|}{ Abdominal pain $\quad \ldots \quad$. } & $\cdots$ & . & 5 & 2 \\
\hline $\begin{array}{l}\text { Diarrhoea } \\
\text { Other... }\end{array}$ & $\therefore$ & $\because$ & $\because$ & 3 & 1 \\
\hline $\begin{array}{l}\text { Other ... } \\
\text { Cardiovascul }\end{array}$ & $\cdots$ & $\cdots$ & & & \\
\hline \multicolumn{2}{|c|}{$\begin{array}{l}\text { Cardiovascular: } \\
\text { Ischaemic heart disease }\end{array}$} & . & . & 7 & 5 \\
\hline \multicolumn{2}{|c|}{ Hypertension .. . . } & . & . & 6 & 3 \\
\hline \multicolumn{2}{|c|}{ Rheumatic heart disease } & .. & . & 9 & 1 \\
\hline \multicolumn{2}{|c|}{ Congenital heart disease } & .. & . & 1 & - \\
\hline \multicolumn{2}{|c|}{ Peripheral vascular disease } & . & .. & 2 & 1 \\
\hline \multirow{2}{*}{\multicolumn{2}{|c|}{ 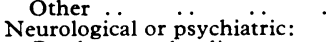 }} & .. & .. & 1 & - \\
\hline & & $\ldots$ & . & 5 & \\
\hline \multicolumn{2}{|c|}{$\begin{array}{l}\text { Neurological or psycniatric: } \\
\text { Cerebrovascular disease } \\
\text { Psychiatric }\end{array}$} & .. & .. & $\begin{array}{l}3 \\
1\end{array}$ & $\overline{7}$ \\
\hline & $\because$ & .. & .. & $\hat{5}$ & 3 \\
\hline \multicolumn{2}{|c|}{ Other diseases: } & & & & \\
\hline \multicolumn{2}{|c|}{ Anaemia or leukaemia } & $\cdots$ & .. & 10 & 3 \\
\hline \multicolumn{2}{|c|}{$\begin{array}{lll}\text { Renal } & . . & \ldots \\
\text { Thyroid } & \ldots & \ldots\end{array}$} & . & * & $\begin{array}{l}5 \\
3\end{array}$ & $\begin{array}{l}1 \\
3\end{array}$ \\
\hline $\begin{array}{l}\text { Thyroid } \\
\text { Metabolic }\end{array}$ & $\because$ & $\cdots$ & $\because$ & 2 & 2 \\
\hline \multirow{2}{*}{$\begin{array}{l}\text { Collagen } \\
\text { P.U.O. }\end{array}$} & $\cdots$ & $\because$ & $\because$ & 1 & 2 \\
\hline & $\cdots$ & . & .. & 0 & 1 \\
\hline \multirow[t]{2}{*}{ Other .. } & . & .. & .. & 2 & 1 \\
\hline & & & & 108 & 66 \\
\hline
\end{tabular}

\section{Communication}

Who Was Who?-In answer to the question (38a) about the identity of people in white coats and uniforms, $27 \%$ of the 174 patients did not know who people were ; $73 \%$ of these thought labels would have helped, and $33 \%$ of the patients who did know who people were would still have liked labels. Thus $43 \%$ of the patients thought labels would have been helpful.

Did the Doctor Tell?-It is a common complaint that patients are not given sufficient details about their illness. We thought that we took particular trouble to explain to patients the nature of their illness and its implications, but Table VIII shows that $39 \%$ of the patients were dissatisfied with the

TABLE VIII.-Replies to Question About Adequacy of Information Compared With Accuracy of Patient's Idea of Diagnosis

\begin{tabular}{|c|c|c|c|c|}
\hline Patient's Reply & & No. & $\begin{array}{c}\text { Diagnosis } \\
\text { Correct }\end{array}$ & $\begin{array}{l}\text { Diagnosis } \\
\text { Wrong }\end{array}$ \\
\hline $\begin{array}{l}\text { Yes } \ldots . . . \\
\text { Yes, but wanted more } \\
\text { Yes, but wanted less } \\
\text { No; wanted more } \\
\text { No; wanted less }\end{array}$ & $\begin{array}{l}\cdots \\
\therefore \\
\therefore \\
\therefore\end{array}$ & $\begin{array}{r}106 \\
31 \\
2 \\
34 \\
1\end{array}$ & $\begin{array}{r}87 \\
25 \\
2 \\
25 \\
0\end{array}$ & $\begin{array}{l}19(18 \%) \\
6(19 \%) \\
9(26 \%) \\
1\end{array}$ \\
\hline
\end{tabular}

information given to them: 65 patients wanted more information and only 3 wanted less. The patient's own idea of his diagnosis (one month after leaving hospital) was compared with the official diagnosis, making allowances for lay terms. Patients with cancer were judged correct if they reproduced the explanation given to them. The less satisfied the patients were with the information given to them the less accurate they were in producing the correct diagnosis. However, even one in six of the satisfied patients were wrong, and this must imply a failure of communication. Three patients made potentially serious mistakes in their diagnosis.

1. A 58-year-old clerk of average intelligence (score 50 in Raven's progressive matrices) who had had a myocardial infarction said he had tuberculosis, although he knew the correct diagnosis as an in-patient.

2. A porter aged 53 said he had suffered from diabetic coma. $\mathrm{He}$ had mild diabetes and was admitted after an epileptic fit.

3. A 73-year-old man with myxoedema thought he had a nervous breakdown. This had happened a year before.

Three patients did not believe our diagnosis.

1. A clerk aged 46 with abdominal pain and nephritis due to Henoch-Schoenlein disease believed he had damaged his kidneys with compound codeine tablets he took to relieve his abdominal pain.

2. A 70-year-old woman with extensive pulmonary tuberculosis, who discharged herself after eight months' treatment, always denied she had tuberculosis.

3. A publican aged 60 did not believe he had coronary thrombosis. He replied, "No idea ; not my heart."

Two patients put a different emphasis on their symptoms.

A 69-year-old man with left ventricular failure and a 75-yearold man with myocardial infarction and pneumonia both replied to the question about diagnosis- "water trouble." Both had minor symptoms of prostatic enlargement. These had been ignored in hospital.

One patient gave a better diagnosis.

He said he was "lonely and run down," which was probably a deeper assessment than the official " relapsed pernicious anaemia due to stopping vitamin $\mathrm{B}_{12 .}$."

TABLE IX.-Replies of Patients With Cancer Well Enough to Answer

\begin{tabular}{|c|c|c|}
\hline Site of Cancer & Patient's Idea of Diagnosis & Comments \\
\hline 1 Bronchus & $\begin{array}{l}\text { Investigation for hoarseness and } \\
\text { loss of weight }\end{array}$ & $\begin{array}{l}\text { Wanted to know more. } \\
\text { Unhappy. Feared }\end{array}$ \\
\hline $\begin{array}{l}2 \text { Stomach } \\
3 \text { Bronchus }\end{array}$ & $\begin{array}{l}\text { Gastric ulcer } \\
\text { Fluid on chest causing breathless- } \\
\text { ness }\end{array}$ & $\begin{array}{l}\text { Satisfied } \\
\text { Died }\end{array}$ \\
\hline $\begin{array}{l}4 \text { Bile-duct } \quad: \\
5 \text { Bronchus } \\
6 \text { Carcinomatosis. }\end{array}$ & $\begin{array}{l}\text { Jaundice } \\
\text { Shadow on lung, infection in tube } \\
\text { Heart weakness causing liver failure }\end{array}$ & $\begin{array}{l}\overline{\text { Satisfied }} \\
\text { Satisfied }\end{array}$ \\
\hline $\begin{array}{l}7 \text { Stomach } \quad \ldots \\
8 \text { Colon }\end{array}$ & $\begin{array}{l}\text { Stomach ulcer } \\
\text { No idea } \\
\text { Getting thin }\end{array}$ & $\begin{array}{l}\text { Wanted to know more } \\
\text { Unhappy. Died }\end{array}$ \\
\hline 10 Bronchus (with & Don't know; am in complete daze & Very unhappy \\
\hline $\begin{array}{l}11 \text { Brourchus } \\
12 \text { Bronchus and }\end{array}$ & $\begin{array}{l}\text { Clot on lung following pneumonia } \\
\text { Osteoarthritis }\end{array}$ & $\begin{array}{l}\text { Died } \\
\text { Died }\end{array}$ \\
\hline $\begin{array}{l}13 \text { Bronchus } \\
14 \text { Pancreas }\end{array}$ & $\begin{array}{l}\text { Clot on lung } \\
\text { Thought it was a gall-stone, but }\end{array}$ & Unhappy \\
\hline \multirow{3}{*}{$\begin{array}{l}15 \text { Oesophagus } . \\
16 \text { Bronchus } \\
17 \text { Kidney } \\
18 \text { Sarcoma pelvis }\end{array}$} & Old age, gullet getting smaller & Satisfied \\
\hline & No idea; wish I knew & Unhappy \\
\hline & Lump on thigh affecting walking & Very fright \\
\hline
\end{tabular}


The Patient with Cancer.-This is a difficult problem and, although none of the patients in this series were told the exact nature of their condition, this is not our invariable policy. In any case, we are careful to ensure that one of the patient's relatives knows the true diagnosis. Table IX shows what the patients said they thought was wrong with them, and indicates what their reaction to this seemed to be. This was based on spontaneous comments which revealed what the patient felt. No assessment could be made in six cases.

\section{After-effects of Hospital Treatment}

In reply to the question (42) asking if the patient should live in any different way as a result of his illness, $30 \%$ of the patients said they had been advised to make changes. Nearly a third of these were impracticable (Table X).

TABLE X.-Changes Advised After Discharge from Hospital

\begin{tabular}{|c|c|c|c|}
\hline \multicolumn{2}{|l|}{ Change } & Practicable & Not Practicable \\
\hline \multirow[t]{2}{*}{$\begin{array}{l}\text { Should change work ( } 7 \%) \\
\text { Should change accommodation (i2\%) } \\
\text { Other changes, e.g., diet, smoking (11\%) }\end{array}$} & $\because$ & $\begin{array}{r}6 \\
12 \\
18\end{array}$ & $\begin{array}{l}6 \\
9 \\
2\end{array}$ \\
\hline & & 36 & 17 \\
\hline
\end{tabular}

\section{Discussion}

The results of this survey are in no way representative of hospitals in general, nor even, necessarily, of our own hospital. They are representative only of the work of one particular general medical firm.

Our patients are partly selected by their general practitioners referring them to a teaching hospital rather than to a nonteaching hospital, and partly because some degree of selection of "suitable" cases was at that time exercised by the admitting medical officer. Many of the patients were admitted from a busy casualty and accident department, and the nature of this service must also provide some degree of selection. The majority of patients were admitted as medical emergencies, a fact related to the severe shortage of medical beds at King's College Hospital.

Most patients were anxious about coming into hospital, although reasonably contented with hospital conditions once they were admitted. There is a small but real risk of additional illness contracted as a result of hospital admission. A third of the patients in hospital were worried by problems, mainly financial, caused by their admission. Hire-purchase debts were not a problem.

One patient in seven was dissatisfied with the food. This compares unfavourably with the Edinburgh survey (McGhee, 1961-all satisfied), and the survey from Manchester (Haywood et al., 1961-8\% dissatisfied). We did not invite detailed criticism of the catering, but this would have been useful.

The patients thought that visiting for half an hour was too short, and one and a half hours too long. We would recommend one hour as satisfying the majority. Most patients did not want open visiting.

Sixty-two per cent. of the patients remembered a teachingward round concerning them. One in ten disliked this. Women, particularly young women, disliked being taught on more than men. This was often for reasons of modesty, and, although this is understandable, it is difficult to know how far one should discriminate in this respect. But it is important that the staff should be aware of this problem. In contrast some patients welcomed teaching as signifying that the doctors were taking a special interest in them.

Nearly half the patients were confused by the multitude of uniforms and different people in white coats, and said they would have liked them to wear name labels. This seems a simple and inexpensive means of removing anxiety. Although the majority of the staff of the hospital support the idea of such labels, a large number disliked the idea of having them.

Two out of five patients were not satisfied with the medical information given to them. We do not believe it is possible to satisfy everybody, but this seems a high proportion of unsatisfied patients, particularly as our own opinion had been that we gave patients considerable information. An even higher proportion of dissatisfied patients (65\%) was recorded from Edinburgh (McGhee, 1961). Five out of six satisfied patients and four out of five dissatisfied patients could give the correct diagnosis. This might suggest that knowledge of the name of the demon is no longer sufficient for its exorcism.

None of our patients with cancer were told the nature of their disease, although this does not mean that we think this should never be done. Nearly half were dissatisfied and unhappy with the information given to them, and only 4 out of 18 were content. This is a very unsatisfactory situation, and it would be valuable to compare the results of a different approach.

The results raise the problem of the most suitable design of hospital wards. While only a few patients actively disliked the communal living in a large open ward, over a third would have preferred to be in single- or four-bedded wards. We tried to analyse this preference of patients in relation to their intelligence, personality, and social background by asking their co-operation in completing appropriate tests, as "diversional" therapy while they were in hospital. An insufficient proportion completed these tests satisfactorily for the results to be meaningful. Nevertheless, it seems probable that because of this deficiency the background needs of patients vary. It is of interest that the private patients' wing of the hospital consists of either single- or four-bedded rooms. But, quite apart from the psychological desires of patients, lack of segregation seems to us to be most undesirable. If more segregation were possible presumably cross-infection and iatrogenic illness would be reduced and patients would be less disturbed by noise. Although there is a Ministry of Health (1961) circular on the subject of noise in hospitals, it is usually impracticable to reduce noise in open wards where some patients may need cylinders of gas by their beds, others need physiotherapy, there is the movement of the staff down the whole length of the ward, and so on.

The present wards with no segregation are designed to provide facilities for the most seriously ill. In fact, few of our patients needed intensive care. The majority should be up during part of the day, yet no proper facilities exist for the comfort of ambulant patients. Segregation would also mean that it would be more feasible to deal with the cigarette-smoking problem which the Ministry of Health (1963) again urge us to do.

King's College Hospital has one of the busiest out-patient departments of any London teaching hospital (225,527 attendances in 1963), yet has the fewest beds (509 in the Group).

This bed shortage is caused by the high proportion of emergency admissions shown in our figures. The continual extra beds that are necessary in the centre of the ward add to the noise because of equipment being moved round them, quite apart from the strain on nursing staff. The diagnostic facilities of the hospital are partly wasted because so many of these medical emergencies are patients with "strokes," heart failure, etc., in whom diagnosis is a small problem. Yet it is difficult to admit many patients who need investigation in hospital. Our results show that there would be a place for hotel-type accommodation for the limited number of such patients who need to be accommodated for investigation. In fact, many of the deficiencies in our service to the patients which are evident from this survey could be rectified if money were available to modernize our present wards so as to achieve some segrega- 
tion even if we cannot plan a new type of ward as those in Crawley New Town can (Sunday Times, 1963).

We believe that surveys such as this are helpful, and practicable even in busy hospitals, and this survey was done without special assistance. The help of medical students was useful in completing Part 1 of the questionary but less valuable than we anticipated. Our patients were pleasantly surprised that anyone should be interested in their personal opinions and were very willing to co-operate. Many found it difficult to conceive of any major shortcoming in the hospital, and tried to find excuses for, rather than express criticisms of, certain faults.

\section{Summary}

A survey of the opinions of patients admitted during a period of six months to a medical firm in King's College Hospital is presented.

Over $80 \%$ of these patients have to be admitted to an open general ward where problems such as noise and the control of infection arise because of the lack of adequate facilities for segregation of patients. However, only $6 \%$ actively disliked the general ward, though $32 \%$ would have preferred to be in a single- or four-bedded room.

Although care is taken to explain to patients the nature of their illness, and three-quarters in fact knew the diagnosis correctly, over one-third were dissatisfied with the explanations they received. The problem of patients with cancer is particularly difficult.

The patient's opinion on visiting-hours, hospital food, medical teaching, etc., is presented and changes that would improve our service from the patient's point of view are discussed.

Our thanks are due to Dr. R. S. Bruce Pearson for allowing us to include patients under his care, and to the administrators and nursing staff of the hospital for their co-operation.

\section{REFERENCES}

Barnes, E. (1961). People in Hospital. Macmillan, London.

Brit. med. F., 1963, 2, 265.

Haywood, S. C., Jefford, R. E., MacGregor, R. B. K., Stevenson, K., and Wooding Jones, G. D. E. (1961). Hospital (Lond.), 57, 644.

Hood, J. D. (1957). Proc. roy. Soc. Med., 50, 217.

McGhee, Anne (1961). The Patient's Attitude to Nursing Care. Livingstone, London.

Ministry of Health (1961). Control of Noise in Hospitals, H.M.(61)68. London.

(1963). Communication Between Doctors, Nurses, and Patients. H.M.S.O., London.

- (1963). Smoking in Hospitals. H.M.(63)43. London.

Nightingale, F. (1863). Preface to Notes on Hospitals, 3rd ed. Longman, Green, Longman, Roberts, and Green.

Sunday Times (1963). The Shape of Wards to Come. 15 December.

\section{Appendix}

The questionary was prepared in three parts. The questions which are relevant to the paper above are appended.

\section{Part 1 (275 Replies)}

This part (items 1-25) simply recorded detailed facts about the patient and his admission to hospital, his dietary treatment, complications of treatment, diagnosis, and condition on discharge (as judged by the doctors).

\section{Part 2 (245 Replies)}

Q26: How did you feel about coming into K.C.H. ?-Mainly anxious/Mainly relieved/Both/Too ill.

Q27: Because of being in hospital have you any financial worries?-No/Loss of earnings/Hire purchase/Other (specify).

Have you other worries ?-No/Family responsibilities/ Business/Other (specify).

Q28: Because of being in hospital are you likely to have any problems on discharge?-No/Yes (specify).

Q29: Patient's idea of diagnosis.

\section{Part 3 (174 Replies) Completed One Month After Discharge}

Q30a: On arrival at the hospital was your reception satisfactory/ unsatisfactory/too ill to bother ?

b: On arrival at the ward was your reception satisfactory/ unsatisfactory/too ill to bother?

Q31a: Did you like being in a general ward with beds along each side as at K.C.H. ? Yes/No. b: There are three types of wards-general as at K.C.H., single-bedded cubicles, four-bedded cubicles. If given a choice, which would you prefer?

Q32: Was the food you had on the whole satisfactory/unsatisfactory?

Q34: Did noise worry you much while you were in hospital ? No/Yes (specify).

Q34a, b: Did you think week-day/week-end visiting too long/ too short/about right?

c: Were your visitors able to come regularly ?

$\mathrm{d}$ : Would you have liked open visiting ?

Q36: Were you, on the whole, during your stay in hospital contented/discontented/concerned? If discontented, because of personal problems/because of hospital conditions (specify)?

Q37: Was there a teaching session round your bed; in which your case was discussed with students? Yes/No. If yes, did you like it/dislike it/feel neutral about it ?

Q38a: Many people in white coats and uniforms dealt with you while you were in hospitals-did you know who they were and what they were doing?

b: Would labels have helped ?

Q39: Did the doctor explain your illness to your requirements ? Yes/No. How much did you want to know ? More than you were told/As much as you were told/As little as possible.

Q40: What do you think was wrong with you ?

Q41: Do you think at the end of your stay in hospital that you were cured/improved/unchanged/worse ?

Q42: As a result of your illness should you live in any different way? Change of accommodation/work/other (specify). Were the changes recommended practicable? 